\title{
Development of Accounting Information System for Small and Medium Enterprises (SME) Batik Bakaran Juwana Pati Central Java
}

\author{
Mukhamad Nurkamid ${ }^{1}$, Sri Mulyani², Budi Gunawan ${ }^{3}$ \\ \{muhammad.nurkamid@umk.ac.id ${ }^{1}$, s.mulyani@umk.ac.id², budi.gunawan@umk.ac.id ${ }^{3}$ \} \\ Informatics Engineering Department, Faculty of Engineering, Universitas Muria Kudus, \\ Gondangmanis PO BOX 53 Bae Kudus ${ }^{1}$, Accountancy Department, Faculty of Economic and Business, \\ Universitas Muria Kudus, Gondangmanis PO BOX 53 Bae Kudus², Electrical Engineering Department, \\ Faculty of Engineering, Universitas Muria Kudus, Gondangmanis PO BOX 53 Bae Kudus $^{3}$
}

\begin{abstract}
Pati Regency has a unique creative industry product, namely batik tulis production from Bakaran village. Local people call this "Batik Bakaran". This creative industry became one of the excellent products of Pati district but until now has not been developed by small and medium enterprisess (SME). The general objective of the Regional Superior Product Development Program is an elaboration of what is contained in the Ministry of Cooperatives and SME's Renstra focusing on five issues: (1)improving the business climate conducive to cooperatives and SMEs, (2)increasing access on productive resources, (3)product development and marketing for SMEs, (4)enhancing the competitiveness of human resources and SMEs, and (5)strengthening of cooperative institutions. The result of this research is SME Batik Bakaran has accounting information system which can be used to manage all needs starting from recording of purchasing process, production process, sales process and financial report consisting of balance sheet and profit / loss.
\end{abstract}

Keywords: batik, bakaran, accounting, information system, SME.

\section{Introduction}

Information technology (IT) is growing rapidly in today's globalization era. The need for all information can be presented easily and varied with the presence of technology early in this millennium era. Moreover, media support (tool) to access technology cheap and easy to get every one. This is seen in the development of the business world (SME) information technology (IT) has become an important and integral part of every business plan[1]. The reason for the use of information technology is applied everywhere and is widely used for business because it can as (1) Communication media, for example, companies with email services that can be used for communication with employees, suppliers, and customers (2) Inventory management, companies must have inventory enough to meet the demand, (3) Managing data, companies must have documents in digital version that can be accessed by everyone in the company. Documents can be stored and accessed quickly from anywhere when needed, (4) Management Information Systems (MIS), the company must be able to manage its data effectively and dynamically. In the business world, the role of MIS is needed, whether for small-scale enterprises (workgroup) or for large-scale (enterprise). Various ICCSET 2018, October 25-26, Kudus, Indonesia Copyright (C) 2018 EAI

DOI 10.4108/eai.24-10-2018.2280628 
conveniences are obtained by business actors by implementing MIS and (5) CRM (Customer Relationship Management), companies use IT to improve and manage customer relationships [1]. In addition to the information can be presented quickly and easily, with the IT users no longer bothered the process of recording each transaction so it will be able to result in data input errors and impact on the information presented becomes inaccurate. One of these processes can be seen in making financial reports of each SME business. The application of financial statements of the computer-based business, business actors easily provide financial accounting information. Financial accounting information is structured to produce information addressed to outside parties, which includes: balance sheet, income statement, cash flow statement, statement of changes in equity and notes to the financial statements. Or in the process of making the financial statements of these sections is known as the financial accounting standard[2]. Management Information Systems (MIS) allows companies to track sales data, costs and productivity levels.

According to Baridwan Zaki (2010) computer applications to be useful has several criteria, including: (1) the information generated should be easy to understand and generate credible decisions; (2) the cost to run the system should be as cheap and as small as possible without sacrificing system benefits (4) the system should be simple, in the sense of being easily operationalized by the person using, and (5) the system should be able to meet the needs of the customers, not only the needs internal company but also external company[3] .

Computer applications become important to apply because it can process data into useful information. With the application of computer-based accounting applications, all data can be analyzed, designed and tested. So with the implementation of this computer-based accounting system can overcome the problem of human error in manual system recordings that have been happening and able to improve the company's performance so that data can be presented quickly, precisely and accurately[4].

Small and Medium Enterprises (SME) batik Bakaran (Adisa and Satria) still use manual financial reporting system. This can be seen from the recording of the sale of goods is still done by writing a manual on the sales book. Manual recording systems have some disadvantages, such as recording errors (writing) that can affect the results of the validity of financial statements and SME inventory reports. In addition, SMEs also have difficulty obtaining accounting information quickly, accurately and accurately in decision making.

From the existing problems, then batik Bakaran SMEs require computer-based financial applications or also called other definition as an accounting information system (AIS). According to $\mathrm{Xu}$ (2009) accounting information systems become one of the important systems because they can record, process, store and distribute information Financial information systems should focus on important factors to minimize business failure, so that the role of stakeholders should be identified: (1) Data procedures, those who create or collect data for AIS, (2) Custodian data, those who design, develop and operate AIS, (3) Customer data, those using accounting information systems, and (4) Data managers, those responsible for managing all data quality in AIS[5]. the use of information technology will not affect SMEs if the user does not participate. participation can be done with users consistently making financial records every day and this is very important to know if SMEs want to advance. The use of information technology is closely related to a person's individual character (the lack of internal information system (IS) expertise in SMEs), organizational characteristics (level of employee' s knowledge) and conditions around him. No matter how good the financial information system is if the behavior of the user is lazy it will not have a good impact and could result in malfunctions of their accounting systems[6],[7]. This is evidence that the use of financial 
information systems greatly influences the performance of SMEs. Even from research there are $90 \%$ of fast food SMEs that do not use the financial information system projected for 5 years will be hired and $60 \%$ of SMEs are asked to improve their financial statements if they want to get up[8].

Financial information systems developed by Rapid Application Development (RAD) development methods RAD was chosen as a system development method because it adopted a waterfall system to produce software with immediate needs and a short time in its completion[9]. The principle of met development RAD ode is identifying all the required application requirements, application design, and implementation. Another advantage of the RAD model, the application can be developed according to the needs of users who often change[10]. James Martin (1992) in his book, "Rapid Application Development", says the main purpose of RAD used is to produce systems with high quality, rapid development, and delivery and low required cost[11]. In harmony with James Martin, Riffat Naz \& M.N.A. Khan (2015) also agrees that RAD facilitates organizations in software development faster and also helps reduce development costs while maintaining software quality[12]. The RAD principles as represented in methodologies such as the recent open standard known as dynamic systems development method which allows customers to provide feedback to the system[13].

In this study produced an information system to help SMEs in managing finances by the name of "Sistem Informasi Keuangan Batik (SIKUBA) Bakaran Juwana, Central Java, Indonesia. In the context of SMEs, accounting information is important as it can help the firms manage their short-term problems in critical areas like costing, expenditure and cash flow, by providing information to support monitoring and control[14],[15]. So this research emphasizes the importance of accounting records that are good for small and medium enterprises. Most managers don't realize the importance of keeping good accounting records. These records must be done regularly and complete with all important data regarding their business transactions[16].

\section{Research methods}

The research method used in this research use approach:

a) Data collection

The data collection method chosen is the interview method and documentation method. Interviews are data collection techniques by directly asking to explore the issues to be studied. Documentation method is to document the type of research data to be processed, ie in the form of data purchase, inventory and sales data.

b) System Development

System development stage in this research using RAD (Rapid Application Development Method) method. The application development of the RAD method is the identification of all the requirements of the application (requirement planning), user design (user design), construction (construction) and released to the user (cutover) [9].

c) Framework 
The framework of thought is a narrative about the conceptual framework of problemsolving that has been identified or formulated in research.

Identification of problems:

- SMEs Batik Bakaran does not utilize production technologies and information technologies in business development

- Making accounting reports difficult to do

- Sales data is still recorded on paper, so it is feared will be damaged

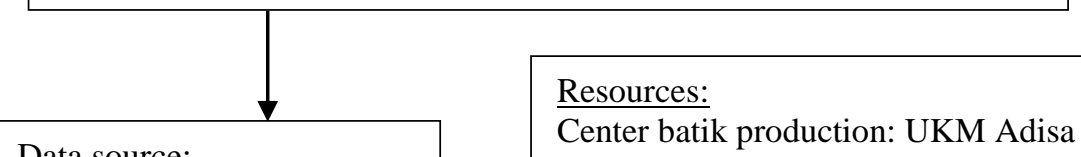

Data source:

The Strategic Plan of The

Cooperative Department

Center batik production: UKM Adisa \& Satria, Bakaran -Juwana, Central

Java, Indonesia.

\section{Results:}

- SME batik Bakaran easier to prepare accounting statements by the name "Sistem Keuangan Batik (SIKUBA)"

- SME batik Bakaran more easily see the profit/loss from the sale of batik

Design:

Accounting Information System (AIS) for small and medium enterprises (SME) batik Bakaran

Fig. 1. Research design framework. 


\section{Results and Discussion}

From this research can be produced the design of several processes that will be incorporated into the information system (Accounting Information Systems). The accounting information system is essentially part of an expansion of a regular information system that collects, processes and reports information related to the financial aspects of business activities[17]. The accounting information system has a broader perspective that not only focuses on financial information but also includes all information such as can be used for management control and performance management[18],[19].

Some of the processes used in accounting information systems of baking batik are: (1) the process of purchasing materials which includes raw materials and auxiliary materials (figure 3), (2) the production process which converts raw materials into ready-to-sell goods, (3) the process of selling finished goods in the form of batik (figure 4), dan (4) external process, that is the recording process starting from purchasing, production and sales recorded in a system consisting of cash receipts and cash expenditures that finally compiled a financial report. The financial statements consist of purchases reports, sales reports, income statements and balance sheets (figure 2).

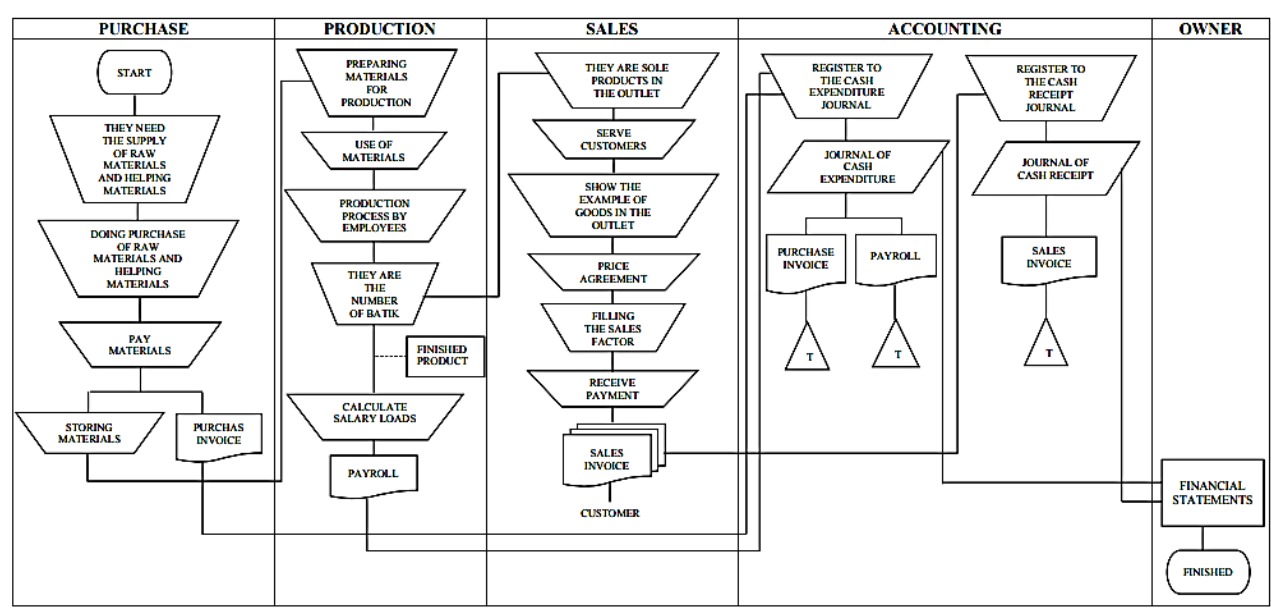

Fig. 2. Flowchart Accounting Information System (AIS) for Small and Medium Enterprises(SME) Batik Bakaran Juwana Central Java. 


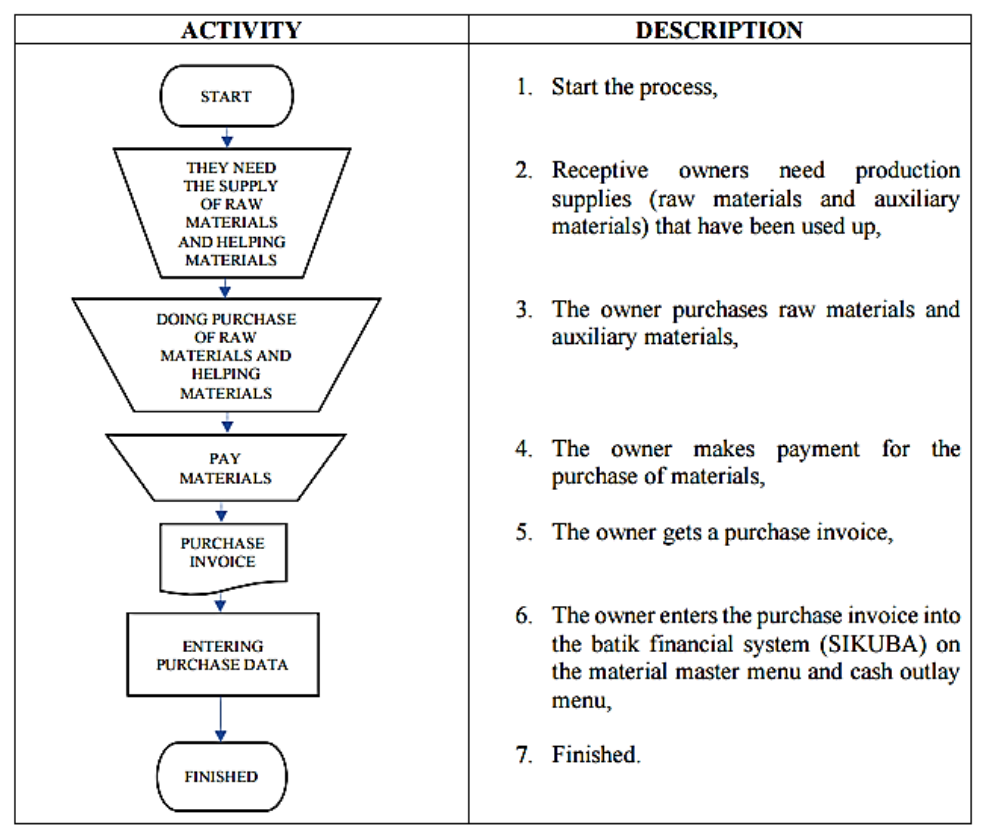

Fig. 3. Purchase flowchart for Accounting Information Sistem Batik Bakaran.

The purchase process is a process that SMEs do to buy materials from batik products. The purchase process consists of receptive owners need production supplies (raw materials and auxiliary materials) that have been used up, the owner purchases raw materials and auxiliary materials, the owner makes payment for the purchase of materials, the owner gets a purchase invoice and The owner enters the purchase invoice into the batik financial system (SIKUBA) on the material master menu and cash outlay menu. 


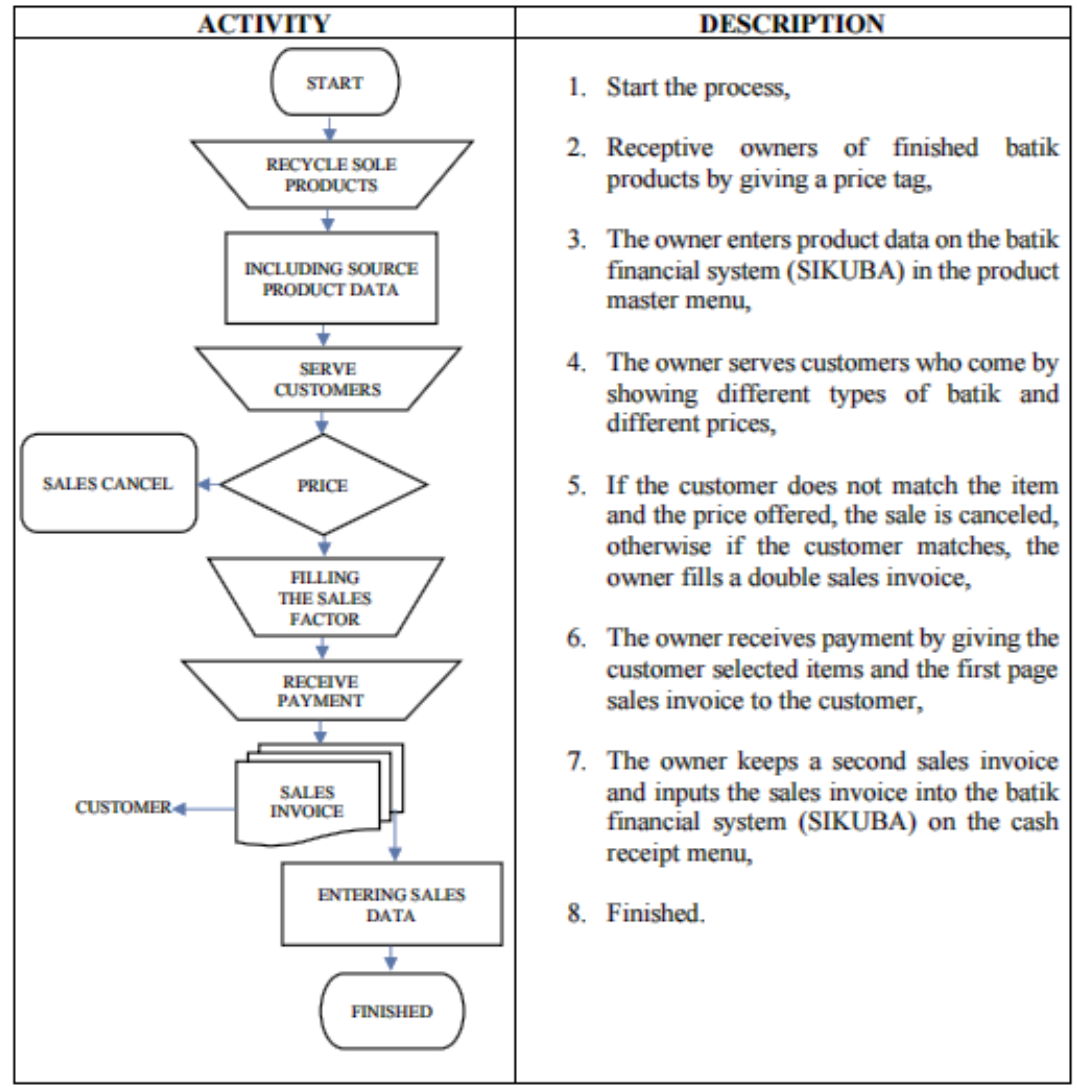

Fig. 4. Sales flowchart for Accounting Information Sistem Batik Bakaran.

In this research has produced accounting information systems to help handle the process of selling batik. The accounting information system of batik handles several input processes, including (1) master batik material, (2) master product, (3) cash receipts, (4) cash outlay, (5) general ledger, and (6) report. Master material is a framework used to handle all materials used for the production process of batik Bakaran, both raw materials, and auxiliary materials. In the material master consists of several attributes: account, material id, material name, category, price, unit, and supplier. With accounting information systems, company performance can be improved. One example is small and medium enterprises in Iraq which can develop with a combination of accounting and accounting information systems[20]. 


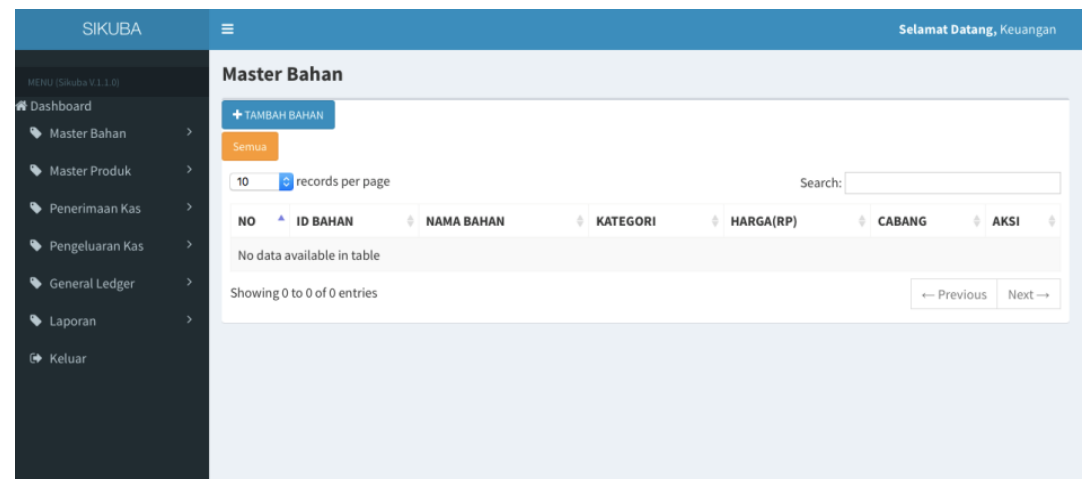

Fig. 5. Material master template.

The product master is a framework that is used to input the types of products produced by SMEs of batik Bakaran. Product master attributes consist of account, product id, product name, category, price, packaging and unit contents. Cash receipts are a framework used to recover money received by SMEs of batik Bakaran.

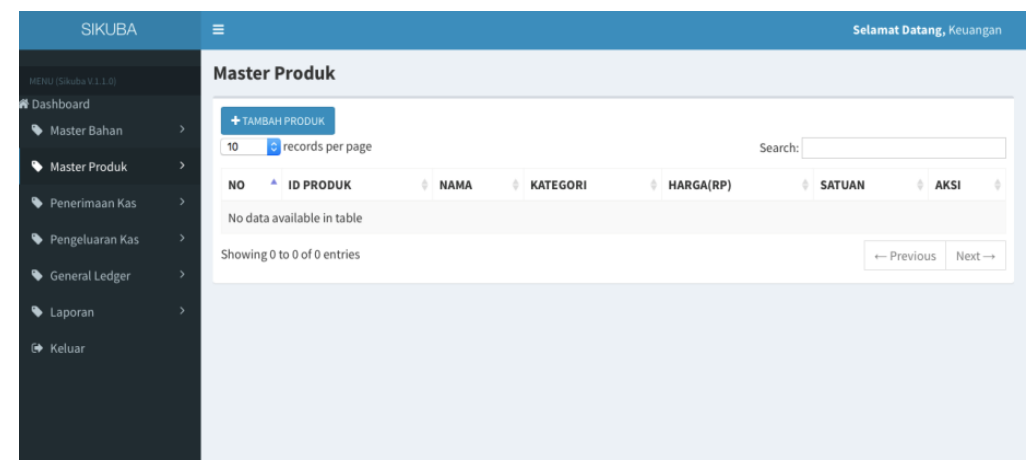

Fig. 6. Product master template.

Cash receipts are the framework used to record money received by SMEs Batik from business activities. Cash receipts consist of several activity forms, namely: (1) Sales invoice, (2) Other receipts and (3) Receivables receivables. Sales invoice purposes to recap and record sales that occur in SMEs batik, which consists of several attributes such as date of sale, agent name and total cost of sales. Another acceptance is to record receipts of money other than sales. Attributes on other forms of acceptance consist of account code, receipts and amount of money received. Receivables are intended to record receivables paid by customers. Attribute form of receivable receipt consists of the payment date of receivables, purchase id, description and amount of cash out. 


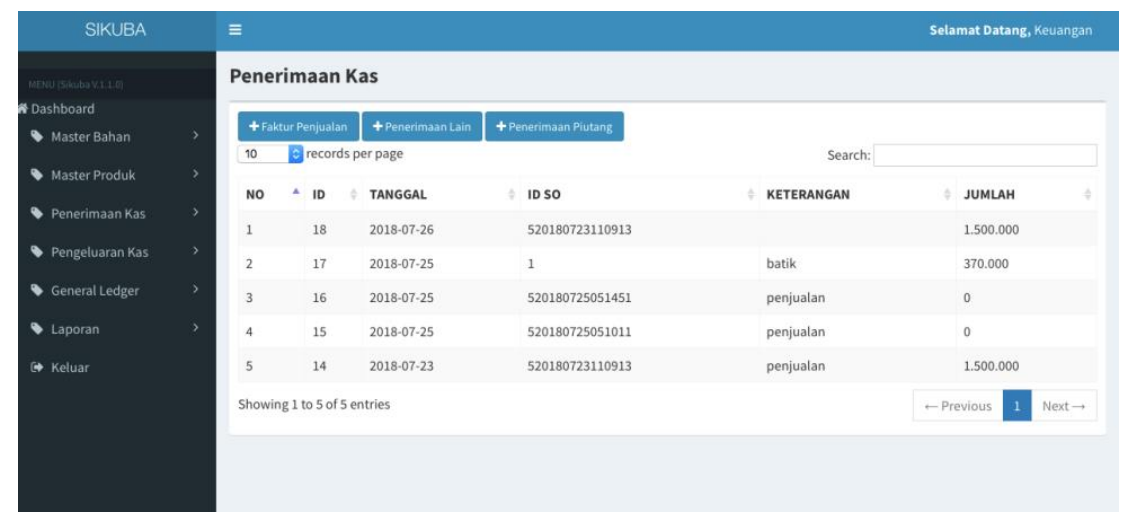

Fig 7. Cash Receipts Framework.

Cash disbursements functioned to record money that has been issued by SMEs in batik business activities. Cash disbursements consist of the menu: (1) purchase invoices, (2) other cash expenses and (3) debt servicing. The purchase invoice is used to record purchases made by SMEs to meet their production needs, which consist of attributes: purchase id, date, supplier and total purchase cost. Another cash disbursement is used to record the money incurred in addition to the purchase of materials. For example load payments. Cash expenditure attributes consist of account code, expense id, description and amount of money paid. Form payment purposes to record debt payments owned by SMEs to suppliers. Attributes on the debt repayment form consist of the supplier name, contact person (supplier) and the amount of debt payable.

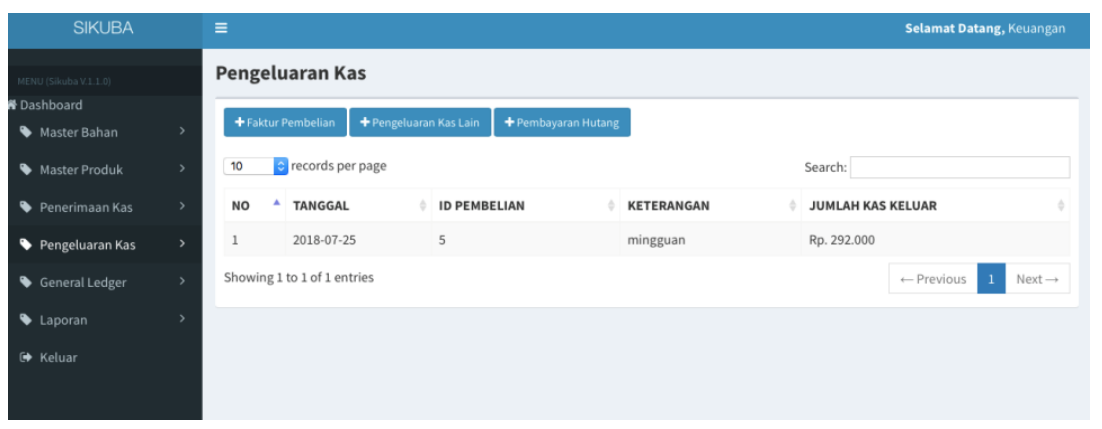

Fig. 8. Cash Expenditure Framework.

Form general ledger purposes to recap all the records inputted in the accounting information system. The report in the accounting information system purposes to display accounting statements consisting of sales reports, purchases reports, profit and loss, and balance sheet. 


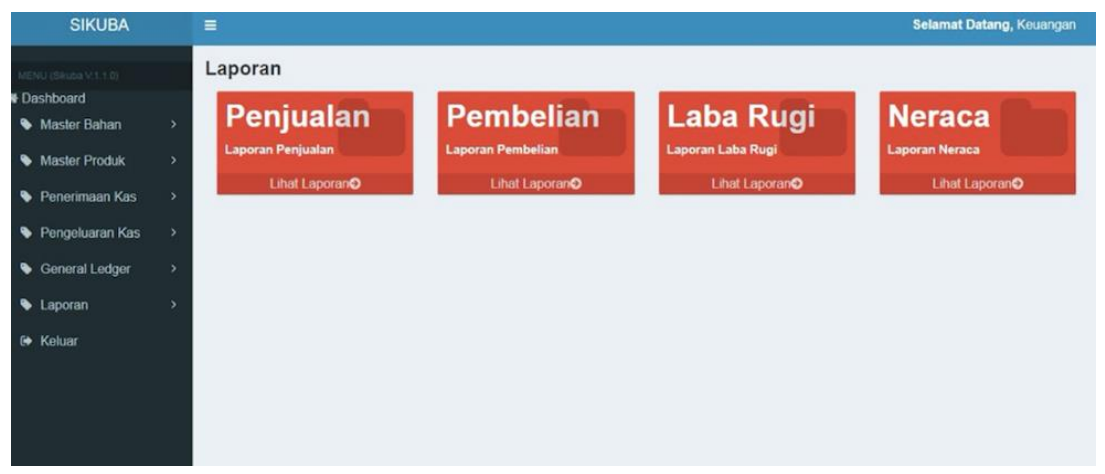

Fig. 9. Report framework.

\section{Conclusion}

From some discussion it can be concluded:

(1) The implementation of the accounting information system, small and medium enterprises (SME) Batik Bakaran can make accounting reports quickly, precisely and accurately according to accounting standard by the name "Sistem Keuangan Batik (SIKUBA).

(2) Accounting information system (AIS) can handle the process of purchasing raw materials, inventories, operational expenses, and sales reports.

(3) The output of the accounting information system can display the balance sheet and income statement.

\section{Acknowledgments}

The programme is funded by Directorate of research and community services Directorate General of Strengthening research and development Ministry of Research, technology and higher education In accordance with the letter of the contract number: 001/LPM.UMK/K6/KM/SP2H/PPM/II/2018

\section{References}

[1] P. Kumar, "Information Technology: Roles, Advantages and Disadvantages," Int. J. Adv. Res. Comput. Sci. Softw. Eng., vol. 4, 2014.

[2] S. A. Hidayat, "Penerapan Sistem Informasi Akuntansi Berbasis Komputer pada Kopinspek PT. Sucofindo Cabang Medan,” J. Wira Ekon. Mikroskil, vol. 2, 2012.

[3] Z. Baridwan, Sistem Informasi Akuntansi. Yogyakarta, 2010.

[4] W. A. A. A. Rochmi Putri Ratnawati, "Perancangan Sistem Informasi Akuntansi Berbasis Komputer Pada Toko Aneka Ragam Banyuwangi (Design of Computer-Based Accounting Information System on 'Toko Aneka Ragam Banyuwangi')," Artik. Ilm. , Jur. Akuntansi, Fak. Ekon. Univ. Jember, 2016. 
[5] H. Xu, "Data Quality Issues for Accounting Information Systems Implementation: Systems, Stakeholders, and Organizational Factors," J. Technol. Res., 2009.

[6] R. M. A. P. Dekeng Setyo Budiarto, "Accounting Information Systems Alignment and SMEs Performance: A Literature Review," Int. J. Manag. Econ. Soc. Sci., vol. 4, pp. 5870, 2015.

[7] D. Fink, "Information System Success In Small and Medium Enterprises: An Evaluation By Australian Public Accountants," AJIS, vol. 4, 2015.

[8] V. Q. Y. V. and J.-P. B. Thembelihle Allah, Puleng August, Siphamandla Bhaza, Tinashe Chigovanyika, Unathi Dyan, Tinashe Muteweye, Mandisi Ngcoza, Neliswa Tshiwula, "Accounting information systems in the fast food industry: A valuable tool for small business survival," African J. Bus. Manag. Business, Cape Penins. Univ. Technol., vol. 7, pp. 260-264, 2013.

[9] I. D. A. E. Y. S. Kosasi, "Penerapan Rapid Application Development pada Sistem Penjualan Sepeda Online,” J. Simetris, Fak. Tek. Univ. Muria Kudus, vol. 6, 2015.

[10] K. P. K. R. K. R. S.Thulasee Krishna, S.Sreekanth, "Explore 10 Different Types of Software Development Process Models,” Int. J. Comput. Sci. Inf. Technol., vol. 3, 2012.

[11] J. Martin, Rapid Application Development. Prentice Hall, USA, 1992.

[12] M. N. A. K. R. Naz, "Rapid Applications Development Techniques: A Critical Review," Int. J. Softw. Eng. Its Appl., vol. 9, 2015.

[13] H. M. D. T. P Beynon-Davies, C Carne, "Rapid application development (RAD): an empirical review," Eur. J. Inf. Syst. 1999.

[14] and S. J. Mitchell, F., Reid, G., "Information System Development in the Small firm: The Use of Management Accounting," CIMAPublishing, 2000.

[15] and M. P. Son, D.D., Marriot, N., "Users Perceptions and Uses of Financial Reports of Small and Medium Companies In transitional Economies: Qualitative Evidence from Vietnam," Qual. Res. Account. Manag., vol. 30, pp. 218-235, 2006.

[16] B. Y. AL Smirat, "The Use of Accounting Information by Small and Medium Enterprises in the South District of Jordan,( An empirical study)," Res. J. Financ. Accounting, Dep. Manag. Financ. Sci. Al-Balqa Appl. Univ. Jordan, Karak, vol. 4, 2013.

[17] P. J. Steinbart, "Editorial: Thoughts about the Future of the Journal of Information Systems,” J. Inf. Syst. Arizona State Univ., vol. 23, 2009.

[18] M. Granlund, "Extending AIS Research to Management Accounting and Control Issues: A Research Note,” Int. J. Account. Inf. Syst., pp. 3-19, 2011.

[19] S. A. L. P. J. S. Severin V. Grabski, "A Review of ERP Research: A Future Agenda for Accounting Information Systems," Sev. V. Grabski, Stewart A. Leech, Pamela J. Schmidt, vol. 25, pp. 37-78, 2011.

[20] E. Harash, "Accounting Performance of SMEs and Effect of Accounting Information System: A Conceptual Model," Glob. J. Manag. Bus. Res. D Account. Audit., vol. 17, 2017. 